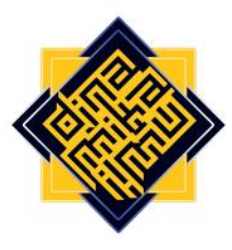

\title{
Developing the School Safety Perception Scale: The Validity and Reliability of Study ${ }^{1}$
}

\author{
Mustafa Kemal ERÇEK \\ MoNE, Teacher, Directorate of Public Education Center, Didim-Aydın, Turkey \\ e-mail:m.kemalercek@icloud.com
}

Fırat KIYAS BİREL

Dicle University Ziya Gökalp Education Faculty, Department of Educational Sciences, Turkey e-mail:firat.birel@dicle.edu.tr

\begin{abstract}
The purpose of this research is to develop a scale to determine the perceptions of teachers working in secondary schools related to school safety. Alongside the social actors, the elements involved in achieving the goals of educational activities are important actors in the solution and implementation of the school security problems. Therefore, the actors performed in this way and were want teachers' perception of safety education activities in schools is critical. The research includes a scale development study. Certain steps in the scale of development for secondary teacher's perceptions of school safety were monitored. Reliability and Validity Scale with work related to the development of exploratory and confirmatory factor analyzes were performed. Exploratory factor analysis of the obtained 40-item scale 54.233 discloses \% of the total variance. Analyzes showed that reliability coefficients of scale factors ranged from .769 to .893 . These values are enough to pass to the confirmatory factor analysis. Confirmatory factor analysis results showed that SSS is a valid tool to measure teachers' perceptions about school safety. Structures of this study, data collected through school safety scale set Cronbach's alpha was calculated in order to determine the internal consistency. Application in terms of behavior and School Safety "Although low compared to other dimensions of size
\end{abstract}

\footnotetext{
${ }^{1}$ This scale is produced from the PhD thesis "The Effect of Teachers in Secondary Schools on School Security Perceptions on Organizational Trust and Professional Commitment"
}

Dinamika Ilmu, Volume 21(1), 2021 
with .61 , scale and reliability coefficients ranged between .80 and .93 for the dimensions have been determined to be highly reliable. Implications for Research and Practice: With the help of the developed scale, relations between school safety perceptions and personal variables, organizational stress, school climate, use of security technologies, occupational burnout and organizational commitment can be examined. Effects of student perceptions of school safety on their academic success can be researched. Similar scales can be developed for parents, administrators, preschool, elementary school teachers, lecturers, and university students.

Keywords: perceptions, scale development, school safety, secondary teachers

\section{A. Introduction}

Societies on school safety sensitivity have been increasing in recent years (Welsh, 2000). School safety problem not only our country, but all developed countries one of the important education problems in recent years has become (Gorman and Pauken, 2003; Daniels, 2002; Sprague, Walker, Golly, White, Myers and Shannon, 2001; Pişkin, 2002; Zinc and Kepenekçi, 2003; Welsh, 2001, Akt: Light, 2004; Welsh, 2000; O'reilly and Verdugo, 1999;Dönmez, 2001; Gottfredson, Gottfredson and Hybl, 1993; Argon and Anderson, 2000; Verdugo, 1999; Benekos, Merlo and Cook, 2002). Schools are more and more insecure becoming environments or people like this perceives. Yet, an unsafe talking about healthy education in an environment cannot be.

The requirements for various knowledge, habits, and expertise that the individual needs to acquire a proper role in society can be associated with the functions of school. Thus, school has a great importance in the life of individuals and society. In today's conditions where human capital is very important, it is imperative that educational institutions create environments that will enable people to develop and realize themselves. This can be accomplished by the priority that educational institutes are structured as safe and healthy organizations. Family, environment, and schools are the main institutions that carry out educational processes. Within these institutions, schools are one of the most important areas where education and training are carried out.

It is of great importance to create effective and appropriate environments in which all elements of a school (students, teachers, administrators, and auxiliary service personnel) will feel safe. Together with the changes in the technological, social, and economic conditions of our time, our schools have a very special position in terms of both initiating and adapting these processes of change. This process of change in society and schools has brought some problems. School security is one of the most basic of these problems that hinders the continuity and success of education.

School safety; students, employees, and the safety of other stakeholders, parents, and visitors, in the school environment "free" in physical, psychological, and social termsis to feel. School safety school only it is not limited by the security of its environment. School the scope and dimensions of its security; your child other school staff to go to schoolfrom the moment he left his home in order to all the stages until you come home again(Işık, 2004; TED, 2006). 
The safety of schools is an issue related to the medium and environment of schools. In other words, the safety of schools is the situation in which students and teachers feel free in their physical, spiritual, and emotional sense. School security is a major problem for teachers as well as for students. Alongside the social actors, the elements involved in achieving the goals of educational activities are important actors in the solution and implementation of the school security problems. School security is one of the main factors that influence teachers, one of these actors is their organizational trust and professional commitment levels.

Healthy and safe school environments help support professional interactions between teachers, leading to an increase in professional commitment levels with a strong emphasis on the academic empowerment of teachers. Thus, a safe school environment shapes the normative environment of the school and develops common values that affect the behavior of teachers. During the teaching process, teachers take more responsibility to improve students 'performance as long as they believe that they can identify and apply effective strategies to support students' learning and that the safe school environment supports teachers. They do not dread from daily obstacles and act to increase students' learning (Education Encyclopedia, 2009: 1). In this context, a safe school climate also supports the organizational trust level by positively affecting teachers, school administrators, and the communication among them.

Security is a vital condition for schools. As Maslow (1943: 371) points out, it is not possible to meet secondary needs (education, self-accomplishment) without security, which is one of the basic physiological needs of people (nutrition, shelter, sexuality). Establishment of security in schools, taking precautionary measures against possible problems (violence, crime, health) and crises (natural disaster, fire, war, etc.) are among the duties of school administrations. The fact that school is an open system constitutes a constant interaction with its environment. Therefore, school environment is an effective factor in school safety. Teachers' feeling confidence increases their motivation. Teachers with a high level of organizational trust are more strongly connected to their jobs and behave towards the objectives of the organization. However, in organizations with a low level of organizational trust, teachers are reluctant to take responsibility and risk. Therefore, establishment of organizational trust in organizations is very important in terms of achieving organizational goals (YIlmaz, 2004: 117).

Schools with safe environments provide good classrooms and schools layouts; increase attitudes, morale, and active involvement levels as well as social interactions (Hernandez and Seem, 2004:24). Failure in determining the perceptions of teachers working in secondary schools on school security is expressed as a problematic condition.

\section{B. Research Objectives}

In this study, it was aimed to develop a data collection tool to measure teachers' perceptions about school safety in institutions that provide secondary education. The aim of this course is to enable the development of a scale that will recognize the perceptions of teachers, who are accepted as the principal elements of schools and have a special 
importance in every society. It is thought that teachers' perceptions are critical in determining the standards related to school security and that the School Security Scale (SSS) will make a significant contribution to the literature.

The scale that is being developed is thought to be an answer to the following questions.

1. What is the perception of teachers about school physical conditions?

2. What is the perception of safety by teachers regarding the external environment of the school?

3. What is the perception of safety of teachers about the general health status of the school?

4. What is the perception of safety by teachers regarding the status of current regulations in the management of the school?

5. What is the teachers' perception of safety in terms of current practices in school administration?

6. What is the perception of safety of teachers about violence at school?

\section{Research Methodology}

Our scale, which was developed in order to determine teachers' perceptions about school safety, was searched in the literature, and questions were developed primarily to create an item pool. Then, these questions were finalized with the opinions of experts, and a six-dimensional scale sample was applied to 250 teachers. All these implementations are explained below as titles and articles respectively.

In the preparation of the School Security Scale (SSS), the studies in domestic and foreign literature were examined and a pool of 56 items in 6 factors was arranged. These factors are "school security in the physical conditions ", "school safety in terms of practices and behaviors ", "school safety in terms of health and cleanliness "," school security in terms of legislations and rules", "school safety in terms of environment" and "school safety in terms of violence".

The items were prepared in accordance with the following steps.

1. While preparing items about school security in physical terms we examined and used some similar questions and factors in studies like doctoral dissertation by Çankaya (2010) in which he used a scale with 35 items and 6 factors (environmental safety, student safety, building safety, student - staff welfare, avoidance of negativity and non-conformity to school), Dönmez and Özer (2009) in which they used a scale with 54 items and 4 factors (violence, physical structure, health, discipline, and rules) and Erçek (2017).

2. In the preparation of the items related to security in terms of the practices and behaviors in the school, we examined the study by Illkay Yener Demirtaş (2007), in which she applied a scale with 52 items and four factors to the administrators and teachers.

3. In preparing the items related to health and cleanliness, we examined "Secondary School Safety" by Turhan and Turan (2012), in which they applied a scale with 23 questions and 6 factors(food safety, safety and security, disaster safety, physical 
environment, traffic, health and addiction) to teachers, students and parents, and used some similar questions.

4. For items about legislation and rules, the scale with 54 items and 4 factors in "School Safety and Safe School" (Dönmez and Özer, 2009) was examined. Some similar questions based on the items in their study were created.

5. For items about environmental safety, we examined and derived some questions from scale items that were used in studies by Turhan and Turan (2012) and Özer (2006).

6. To prepare items related to violence, we examined the study by Ögel, Tarı and Yılmazçetin Eke (2005) and created some similar items they used in their book.

Finally, to ensure the validity of the 56-item scale, expert academicians were consulted. The item pool was applied to 250 secondary school teachers in 2015-2016 semesters in Diyarbakır in a pilot application. Answers of 152 participants were evaluated. According to formula by Karasar (2005), sampling number is enough to represent the universe with $\% 95$ reliability interval.

With the data obtained from the pilot application, reliability, validity, explanatory and confirmatory factor analyzes of the School Safety Scale, which is the data collection tool developed, were made. Item size correlation analysis, item analysis, and KMO Bartlett's Test were conducted. According to these analyzes and anti-image correlation matrix, developed scale was found to be appropriate for factor analysis. Then, exploratory and confirmatory factor analyzes were performed, and reliability and validity of the scale were determined.

\section{Findings and Results}

\section{Findings Related to the Reliability of School Safety Scale}

Item- factor correlation analysis was made with 56 items and 6 factors. Correlation analyzes were made with item mean scores to determine the contribution that items make to the factor and which items should be omitted. After correlation analysis, correlation coefficients of item $4(r=-.134, p=.099)$ and item $7(r=-.114, p=163)$ in "safety in terms of health and hygiene" factor were found to be lower than 0.30 and therefore, these items were deleted.

Item analysis were made to determine the contribution of the items to their factors' reliability. Reliability of factors was calculated as "safety in terms of physical conditions" ( $\alpha$ $=.814)$, safety in terms of legislation and rules $(\alpha=.714)$, safety in terms of practices and behaviors ( $\alpha=.851)$, environmental safety $(\alpha=.749)$, safety in terms of health and hygiene ( $\alpha=.719)$, safety in terms of violence (psychological, sexual, economic and physical violence) $(\alpha=.882)$. Also, Cronbach alfa values of factors ranged from 0.71 to 0.88 after each item deleted individually in each factor.

When reliability coefficients of the factors were evaluated, the lowest reliability coefficient ( $\alpha=0.71$ ) was found to be "quite reliable ", and the highest one $(\alpha=0.88)$ was found to be "highly reliable". Deletion of each item did not change the reliability of their factors significantly. Therefore, no item was deleted from the scale at this stage (Büyüköztürk, Şekercioğlu, and Çokluk, 2014). 
Anti-image correlation matrix showed that item 3 in "safety in terms of legislation and rules" and item 10 in "safety in terms of health and hygiene" had correlation coefficients lower than 0.5. For this reason, these two items were excluded from further analysis.

After these results, for the remaining 54 items $\mathrm{KMO}$ and Bartlett sphericity test were performed to check the suitability of the data set for factor analysis. The results of this test are given in Table 1 below.

Table 1.KMO and Bartlett Test

\begin{tabular}{rll}
\hline Kaiser-Meyer-Olkin & .78 \\
\hline & $x^{2}$ & 4212.366 \\
Bartlett's Sphericity Test sd & 1326 \\
$\mathrm{p}$ & .000 \\
\hline
\end{tabular}

According to $\mathrm{KMO}$ and Bartlett sphericity test, $\mathrm{KMO}$ value was calculated as 0.78 , and $p$ value for Bartlett test was found to be lower than 0.05 . These findings suggest that data set and sampling size are suitable for factor analysis.

\section{Findings related to the validity of School Safety Scale}

KMO and Bartlett test were applied to check the suitability of the sample size and the data set for factor analysis. The anti-image correlation matrix, which is an alternative method for the analysis of whether the R-matrix obtained from the variables before the $\mathrm{KMO}$ and Bartlett tests is suitable for factor analysis, is calculated. Anti-image correlation matrix was calculated for the remaining 52 items after subtracting item 4 and item 7 . Items with a correlation coefficient of lower than 0.50 were removed. After determining that the data set was suitable for factor analysis, confirmatory factor analysis was performed after exploratory factor analysis in order to determine the construct validity of the scale.

\section{Findings related to Exploratory Factor Analysis}

In order to determine the factor structure of the scale, exploratory factor analysis was performed. Factor analysis aims to create new variables (sub-dimensions) that are unrelated to each other and conceptually meaningful by bringing together the variables associated with each other into certain groups (factors) (Tavşancil, 2010:46).

Factor load value is a coefficient explaining the relations of items with factors. It is expected that the factor load values of the items are high. (Büyüköztürk, Şekercioğlu, Çokluk, 2014: 194) Generally, the minimum load value for an item is accepted to be 0.30 and greater. However, there are theorists who argue that it should be 0.40 minimum. (Büyüköztürk, Şekercioğlu, Çokluk, 2014: 194) According to this information, the lowest factor load was accepted as 0.40 and items with lower load values were excluded from the analysis. 
As a results of factors analysis of the SSS were determined as, "violence", "physical conditions", "health and hygiene", "legislation and rules", practices and behaviors", and "environment".

As a result of Principal Components Factor Analysis with Varimax rotation, it was found that item 6 and item 7 were not suitable for the "legislation and rules" factor and therefore subtracted from the analysis. Item 1, 2, 3 and 7 in the "practices and behaviors" factor were not suitable items for their factors and therefore deleted. Also, item 8 in this factor was deleted due to a low factor load value. Items 1 and item 2 in the "environment" factor were not suitable for this factor, and item 8 had a low factor load value. These items were also deleted. The results of Factor Analysis of Basic Components with Varimax Rotation are given in Table 2. Item 10 in "violence" and item 3 in "health and hygiene" had factor load values lower than 0.40 and therefore were excluded from further analysis. The results of the principal component analysis with varimax rotation are shown in table 2 .

Table 2. Exploratory Factor Analysis

\begin{tabular}{|c|c|c|c|c|c|}
\hline Factors & Item & $\begin{array}{l}\text { Factor } \\
\text { Load } \\
\text { Values }\end{array}$ & $\begin{array}{l}\text { Eigen } \\
\text { value }\end{array}$ & $\begin{array}{l}\text { \% } \\
\text { Variance } \\
\text { explained }\end{array}$ & $\begin{array}{l}\text { Cronbach } \\
\text { Alfa }\end{array}$ \\
\hline \multirow{9}{*}{ 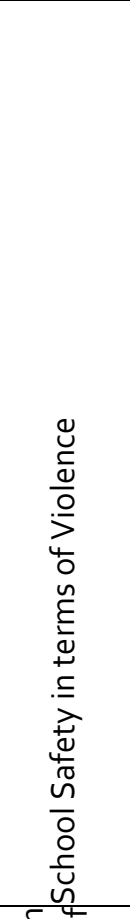 } & $\begin{array}{l}\text { Our school has experienced incidents of sexual } \\
\text { harassment against teachers by students }\end{array}$ & 0.763 & \multirow{9}{*}{9.691} & \multirow{9}{*}{24.229} & \multirow{9}{*}{.893} \\
\hline & $\begin{array}{l}\text { The students experienced sexual harassment among } \\
\text { themselves. }\end{array}$ & 0.759 & & & \\
\hline & $\begin{array}{l}\text { There have been } \\
\text { students/teachers/administrators/parents who have } \\
\text { suffered or died in violence incidents in our school. }\end{array}$ & 0.724 & & & \\
\hline & $\begin{array}{l}\text { In our school, there are often theft and extortion } \\
\text { cases. }\end{array}$ & 0.717 & & & \\
\hline & $\begin{array}{l}\text { I have witnessed the introduction of firearms or } \\
\text { cutting tools to the school by } \\
\text { students/teachers/administrators/other personnel. }\end{array}$ & 0.709 & & & \\
\hline & $\begin{array}{l}\text { I witnessed parents' physical violence against } \\
\text { teachers. }\end{array}$ & 0.685 & & & \\
\hline & $\begin{array}{l}\text { Mobbing (psychological pressure, mobbing, } \\
\text { intimidation, intimidation, harassment) events are } \\
\text { experienced in our school. }\end{array}$ & 0.651 & & & \\
\hline & $\begin{array}{l}\text { At school, students use physical violence against } \\
\text { teachers. }\end{array}$ & 0.638 & & & \\
\hline & $\begin{array}{l}\text { In our school, there are often threats and blasphemy } \\
\text { incidents. }\end{array}$ & 0.628 & & & \\
\hline \multirow{2}{*}{ 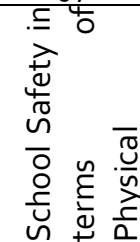 } & $\begin{array}{l}\text { In the laboratory and workshops, necessary safety } \\
\text { measures (such as toxic, flammable, flammable, } \\
\text { explosive, etc.) are taken and controlled regularly. }\end{array}$ & 0.719 & \multirow[t]{2}{*}{4.801} & \multirow[t]{2}{*}{12.003} & \multirow[t]{2}{*}{.814} \\
\hline & $\begin{array}{l}\text { Our school is well equipped for natural disasters } \\
\text { (earthquake, flood, hurricane, fire etc.). }\end{array}$ & 0.702 & & & \\
\hline
\end{tabular}




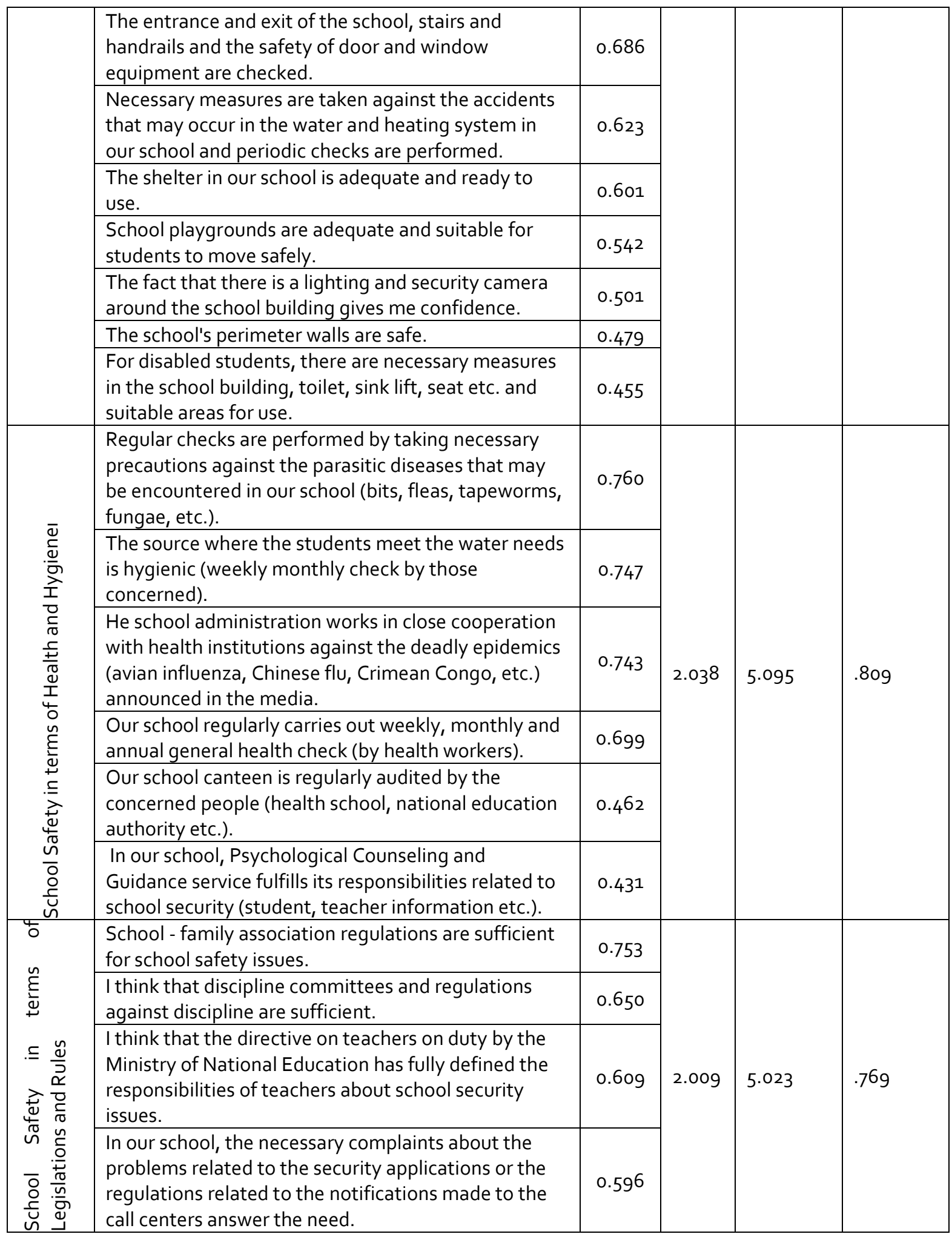


Developing the School Safety Perception Scale

\begin{tabular}{|c|c|c|c|c|c|}
\hline & $\begin{array}{l}\text { The Ministry of Education's school safety plan has } \\
\text { sufficient general plan and instructions for school } \\
\text { safety. }\end{array}$ & 0.494 & & & \\
\hline \multirow{6}{*}{ 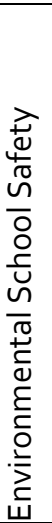 } & $\begin{array}{l}\text { His fact that our school students are able to easily } \\
\text { provide the publication (pornographic publications } \\
\text { and visuals) poses a threat to school security. }\end{array}$ & 0.739 & \multirow{6}{*}{1.687} & \multirow{6}{*}{4.218} & \multirow{6}{*}{.769} \\
\hline & $\begin{array}{l}\text { The presence of playrooms and alcoholic } \\
\text { entertainment venues around the school pose a } \\
\text { threat to school safety. }\end{array}$ & 0.653 & & & \\
\hline & $\begin{array}{l}\text { There are security risks in the vicinity of the school, } \\
\text { such as transformers, fuel stations, base stations or } \\
\text { airports }\end{array}$ & 0.636 & & & \\
\hline & There are drug users and sellers around our school. & 0.626 & & & \\
\hline & There are school gangs inside and outside our school. & 0.605 & & & \\
\hline & There are terrorist incidents in our school. & 0.498 & & & \\
\hline
\end{tabular}

\begin{tabular}{|c|c|c|c|c|c|}
\hline \multirow{5}{*}{ 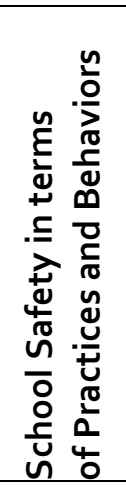 } & The reason for visiting the visitors is recorded. & 0.655 & \multirow{5}{*}{1.466} & \multirow{5}{*}{3.665} & \multirow{5}{*}{.781} \\
\hline & $\begin{array}{l}\text { I think that the teachers on duty in our school have } \\
\text { done their duties about school safety. }\end{array}$ & 0.627 & & & \\
\hline & $\begin{array}{l}\text { In the case of fire, earthquake, nuclear, biological } \\
\text { and chemical attacks on our boards, relevant } \\
\text { sabotage and disaster response regulations are } \\
\text { hung and updated }\end{array}$ & 0.508 & & & \\
\hline & $\begin{array}{l}\text { The wishes and complaints about the security } \\
\text { problems in our school are evaluated and finalized. }\end{array}$ & 0.461 & & & \\
\hline & I have enough information about first aid training. & 0.408 & & & \\
\hline & $\begin{array}{l}\text { Note: Principal component analysis with varimax } \\
\text { rotation \& excluded items: } 19-20-24\end{array}$ & & & & \\
\hline
\end{tabular}

After all these analyzes, the draft scale with 40 items and 6 factors was acquired. Factor load values of items, Eigen values, percentage of variance explained, and reliability values of factors are presented in the table above. The 40-item scale explains \%54.233 of the total variance. "School Safety in terms of Violence" factor was found to be the factor with the highest variance explained value of \%24.229. Reliability values of the factor ranged from 0.769 to 0.893 . These results are enough to do confirmatory factor analysis.

\section{The findings related to the confirmatory factor analysis}

Confirmatory Factor Analysis (CFA) is an analysis method that is frequently used in the development of measurement models and provides important facilities. This method is a process to create a latent variable based on the variables observed through a model that was created before (Myers, 2000).

It is mostly used in scale development, and validity analyzes or aims to verify a previously determined structure (Bayram, 2010). DFA is used to define multivariate statistical analyzes, which contain latent structures represented by a large number of observed or measured variables (Bayram and Bilgel, 2008). CFA is the factor analysis used 
to test the conformity of the factors determined by the Explanatory Factor Analysis (EFA) with the hypothesis-determined factor structures. While EFA is used to test which variable groups are highly correlated with which factor, CFA is used to determine whether the variable groups that contribute to the specified number of factors are sufficiently represented by these factors. In CFA, researchers are expected to determine the correlation between measurement errors, and the correlations of the factors are expected to be equal (Günden and Miran, 2008). The model can be theoretically determined by the researcher and tested with CFA or a model obtained as a result of EFA. The relationship of each item with the presumed hidden variable, which is the only self-declared variable, was defined in the model, and the model was formed with the theoretical assumption that the relationship with other latent variables was 0.

There are many goodness of fit indexes and criteria for controlling the validity of the model created by confirmatory factor analysis. In this study, we tried to reveal the validity of the model with indexes that are most preferred in the literature (AGFI, CFI, RMSEA, RMR, and IFI). The goodness of fit test for the scale is given in Table 3 below.

Table 3. Goodness of fit

\begin{tabular}{llllll}
\hline $\boldsymbol{x}^{2} / \mathrm{df}$. & AGFI & CFI & RMSEA & RMSR & IFI \\
\hline 1.63 & 0.88 & 0.90 & 0.06 & 0.08 & 0.94 \\
\hline
\end{tabular}

$\chi^{2}$ / degree of freedom values of lower than 3, RMSEA values around 0.05, GFI, AGFI, CF values greater than .90, and RMSR values lower than 0.1 usually show that the model has a good fit. Since $\chi^{2}$ value will be higher with greater number of variables, $\chi^{2} /$ degrees of freedom is utilized (Tak \& Çiftçioğlu, 2009).

$\chi^{2} / \mathrm{df}$. ( chi-square Normed; NC) value is 1.63, AGFI (Joreskog corrected goodness of fit index) value is .875, CFI (Bender's comparative fit index) value is .903, RMSEA (The Root Mean Square Error of Approximation) value is .061, RMSR: (Remainder Mean Square Root) value is 0.82 . IFI Incremental Fit Index value is .939. According to the data obtained as a result of confirmatory factor analysis, and given criteria, it can be argued that the fit index values show that the model has a good fit, in other words, the 6-factor structure is an acceptable model.

In the confirmatory factor analysis, a latent variable is a six-factor structure, and when these implicit variables are called dependent variables, and the items that try to explain these implicit variables are considered as independent variables, the model diagram is as follows. 


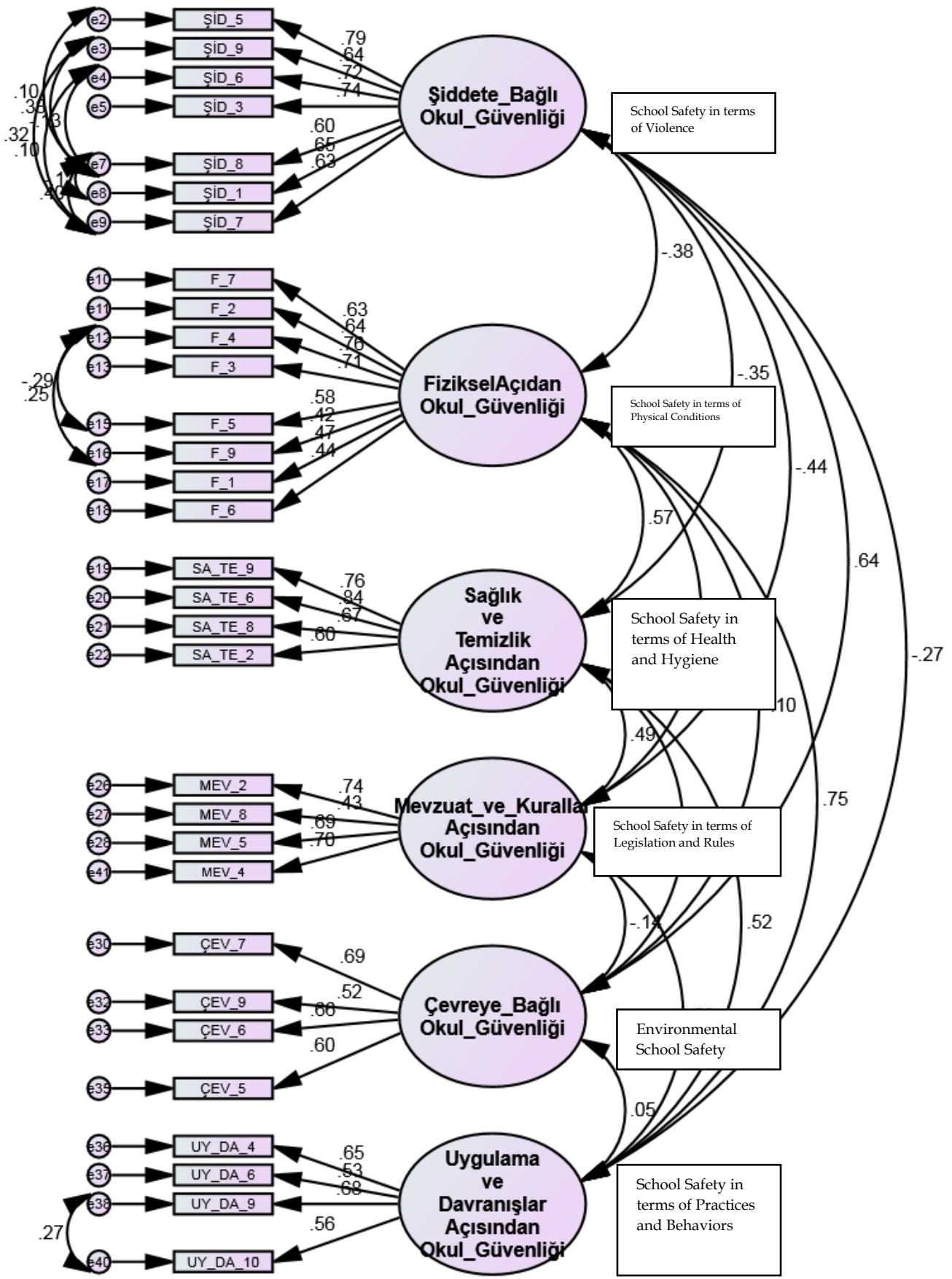

Figure 1. School Safety Scale Standardized Values Diagram for Confirmatory Factor Analysis 
Figure 1 above shows the effect coefficients and correlation coefficients of each independent variable on the implicit dependent variable.

It was found that correlation coefficients items related to "violence" factor (Psychological, Sexual, Economic and Physical Violence) are between .42 and. 76, the correlation coefficients for the items related to the "physical condition" factor are between .42 and .76 , correlation coefficients of items related to "health and hygiene" are between.60 and. 84, correlation coefficients of items related to "legislation and rules" are between .43 and. 74, correlation coefficients for items related to "practice and behaviors" are between .53 and .68, and correlation coefficients of items related to "environment" are between .60 and .69.

In the light of findings obtained from confirmatory factor analysis, it can be said that SSS is a valid tool that can measure teachers' perception levels about school safety. In Table 4, Cronbach's Alpha values and item numbers of factors were given.

Table 4. Reliability Analysis for SSS

\begin{tabular}{lll}
\hline Factors & Cronbach's & \\
\hline School Safety in terms of Violence & Alpha & Number of Items \\
School Safety in terms of Physical Conditions & 0,94 & 7 \\
School Safety in terms of Health and Hygiene & 0,80 & 8 \\
School Safety in terms of Legislation and Rules & 0,79 & 4 \\
Environmental School Safety & 0,87 & 4 \\
School Safety in terms of Practices and Behaviors & 0,87 & 4 \\
School Safety Scale & 0,61 & 4 \\
\hline
\end{tabular}

\section{E. Conclusion}

In this study, Cronbach Alpha coefficient was calculated in order to determine the internal consistency of the data set collected by SSS. When the Cronbach Alpha coefficients are examined in Table 4 above, it can be seen that the lowest is 0.61 for the "practices and behaviors" factor. Although it is lower compared to coefficients of other factors, it is still quite reliable. Coefficient values of other factors and the scale itself are between 0.79 and 0.94 , which means that they are highly reliable. As a result of the CFA analysis, SSS was prepared as a 31-item scale with six factors in the tables below. While calculating the scores of the teachers' answers in the analysis of the data, "Strongly Disagree" scored as 1 point, " Disagree "scored as 2 points, "Undecided" scored as 3 points, "Agree" scored as 4 points, and "Strongly Agree" scored as 5 points. In the School Safety Perception Scale, all items of "violence" and "environment" factors are negative and therefore scored in reverse.

\section{F. Suggestions}

Some suggestions are made for the researchers and practitioners according to the results obtained in the study and the scale developed. Firstly, the school security scale which was developed was pre-applied on teachers. A similar scale can be developed to measure 
parents and pupils' perceptions of school safety can be. In addition, a scale for academician's perceptions about university campus security can be developed. Similarly, a different scale could be developed for university students. Again, the scale of school security with more sub-factors can be rearranged. The perception of safety for kindergartens can be determined by developing a scale for teachers, administrators and parents. With the help of the developed scale, relations between school safety perceptions and personal variables, organizational stress, school climate, use of security technologies, occupational burnout and organizational commitment can be examined.

\section{BIBLIOGRAPHY}

Astor, R. A., Benbenisbty, R., Marachi, R., \& Rosemond, M. (2005). School Safety Interventions: Best Practices and Programs. Children \& Schools, V: 27, Nu: 1 January.

Argon, J., Anderson, L. (2000). School security by the numbers. American School and University, 72(1), C1-C11.

Bayram, N \& Bilgel, N. (2008). Evaluating life standards of Turkish immigrants in Sweden with Structural Equation Models. 9. Symposium of Econometry,

Bayram, N. (2010). Introduction to Structural Equation Modeling. Ekin Kitabevi İzmir.

Benekos, P. J., Merlo, V., Cook, B. (2002). A priliminary study of student attitudes of juvenile justice system. Journal of Criminal Justice Education, 13(2), 273- 296.

Bursalıŏlu, Z. (2003). Theory and Practice in Education Management, Pegem A Yayınları.

Büyüköztürk, Ş., Şekercioğlu, G. V., \& Çokluk, Ö. (2014). Multivariate Statistics for Social Sciences: Applications of SPSS and LISREL . 3. Print, Pegem A Yayınları.

Büyüköztürk, Ş., Çakmak, E. K., Akgün, Ö. E., Karadeniz, Ş., \& Demirel, F. (2014). Scientific Research Methods. 18. Print, Pegem Akademi.

Çankaya, İ. (2010). The Effect of School Security on Primary School Teachers' Anxiety, Motivation and Job Satisfaction Levels. Unpublished PhD Thesis, Firat University, Social Sciences Institute.

Demirtaş, I. Y. (2007). Primary School Teachers and Teachers' Roles and Expectations Regarding Security. Unpublished master thesis, Sakarya University, Social Sciences Institute

Dönmez, B. (2001). Okul Güvenliği Sorunu ve Okul Yöneticisinin Rolü. Kuram Ve Uygulamada Eğitim Yönetimi, 7(25), 63-74.

Dönmez, B \& Özer, N. (2009). School Safety and Safe School. Ankara: Nobel Yayınevi

Education Encyclopedia. (2009). School climate - measuring school climate, school celimate and outcomes, issues trends and controversies. Date of access: 23.07.2018, http://education.stateuniversity.com/pages/2392/School-Climate.html

Erçek ,M.K.(2017) The Role of School Security from Factors Affecting Teachers' Engagement: Akademic Social Research Journal, Year: 5, Issue: 49, July 2017, p. 478496 
Günden, C \& Miran, B. (2008). Determining the Environmental Attitudes of the Farmers with the New Environmental Paradigm Scale: The Case of Torbalı District of Izmir Province, $18,69,41-50$.

Gorman, K. \& Pauken, P. (2003). The ethics of zero tolerance. Journal of Educational Administration, 41 (1), 24-36.

Gottfredson, D. C., Gottfredson, G. D., \& Hybl, L. G. (1993). Managing Adolescent Behavior: A Multi-Year, Multi-School Experiment. American Educational Research Journal, 30(1), $179-216$.

Işık, H. (2004). Okul Güvenliği: Kavramsal Bir Çözümleme. Milli Eğitim Dergisi, S:164, Güz2004, MEB yayınları

Hernandez, T. J \& Seem, S.R. (2004). A safe school climate: A systemic approach and the school counselor. Professional School Counseling, 7(4). Date of access: 22.07.2018 http://www.schoolcounselor.org/files/7-4-256\%2oHernandez.pdf

Hosmer, L. T. (1995). Trust, The Connecting Link Between Organizational Theory and Philosophical Ethics. Academy of Management Review, 20, 379-403.

Joreskog,K.G. \& Sorbom, D.(1993). Structural Equation Modeling with the SIMPLIS Command Language. From<http://books.google.com.tr/books?id=f6iizquHcv4C>

Karasar, N. (2005). Scientific Research Method. Ankara Nobel Yayinlari Press

Maslow, A. H. (1943). A theory of human motivation. Psychological Review, 50 (4): 370-396.

Myers, W. H. (2000). A structural equation model of family factors associated with adolescent depression. The University of Memphis. ProQuest Dissertations Publishing

O'reılly, E. M., Verdugo, R. R. (1999). Safe School Indicators: The Data and Social Policy. Education and Urban Society, 31 (3), 334-348.

Özer, N. (2006). Secondary School Students' Perceptions About School Safety. Unpublished Science Expertise Thesis, İnönü University, Social Sciences Institute.

Öğel, K\& Tarı, I. \& Eke, C. Y. (2005). Prevention of Violence and Violence in Schools. Yeniden Yayınları no:17.

Payne, A.A., Gottfredson, D.C., Gottfredson,G.D. (2003). Schools as Communities: The Relationship Between Communal School Organization, Student Bonding, and School Disorder. Criminology, 41:749-778.

Pişkin, M. (2002). Okul Zorbalığı: Tanımı,Türleri, İlişkili Olduğu Faktörler Ve Alınabilecek Önlemler. Kuram Ve Uygulamada Eğitim Bilimleri, 3 (2), 531-562.

Tak, B \& Çiftçioğlu, B. A. (2009). A Field Study on the Reliability and Validity of the Three Dimensional Professional Commitment Scale in Turkish. Management Faculty Journal, 10(1),35-54.

Tavşancıl, E. (2010). Measuring attitudesande SPSS Data Analysis. Nobel Yayın Dağıtım.

Turhan, M \& Turan, M. (2012). Safety in Secondary School Institutions. Education Management: Theory and Practice, 18(1),121-142.

Wagner, R. (2002). School Violence in Children and Adolescents: A MetaAnalysis of Effectiveness. Journal of School Violence, 1: 5-34.

Welsh, W. N. (2000). The effects of school climate on school disorder. Annals of The American Academy of Political and Social Sciences (Annals-Aapss), 567, 88-107.

50 Dinamika Ilmu, Volume 21(1), 2021 
Yılmaz, K. (2004). The opinions of primary school teachers about the relationship between supportive leadership behaviors of school administrators and school trust. Journal of Inönü University Faculty of Education, 5(8), 117-131.

Appendix

Table Teacher Perceptions of School Safety Scale (SSS)

\begin{tabular}{|l|l|l|l|l|}
\hline \multicolumn{1}{|c|}{$\begin{array}{l}\text { Conditions } \\
\text { Teacher Perceptions of School Safety in terms of Physical }\end{array}$} & & & & \\
& & &
\end{tabular}

\begin{tabular}{|c|c|c|c|c|c|}
\hline $\begin{array}{l}\text { Teacher Perceptions of School Safety in terms of In-School Practices } \\
\text { and Behaviors }\end{array}$ & 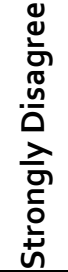 & 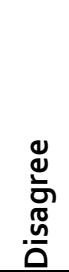 & $\begin{array}{l}\text { 믐 } \\
\frac{d}{0} \\
\underline{\partial}\end{array}$ & 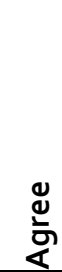 & 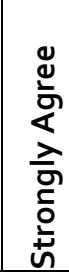 \\
\hline \multicolumn{6}{|l|}{ 1. The reason for visiting the visitors is recorded. } \\
\hline \multicolumn{6}{|l|}{$\begin{array}{l}\text { 2. I think that the teachers on duty in our school do their duties about } \\
\text { school safety. }\end{array}$} \\
\hline $\begin{array}{l}\text { 3. In the case of fire, earthquake, nuclear, biological and chemical attacks } \\
\text { on our boards, relevant sabotage and disaster response regulations are } \\
\text { hung and updated. }\end{array}$ & & & & & \\
\hline
\end{tabular}


4. I have enough information about first aid training.

\begin{tabular}{|c|c|c|c|c|c|}
\hline $\begin{array}{c}\text { Teacher Perceptions of School Safety in terms of Health and } \\
\text { Hygiene }\end{array}$ & 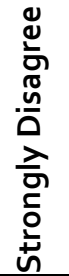 & 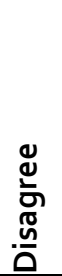 & 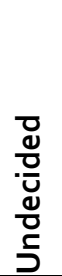 & 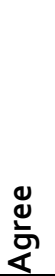 & 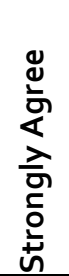 \\
\hline $\begin{array}{l}\text { 1. Our school regularly carries out weekly, monthly and annual general } \\
\text { health check (by health workers). }\end{array}$ & & & & & \\
\hline $\begin{array}{l}\text { 2. The source where the students meet the water needs is hygienic } \\
\text { (weekly monthly check by those concerned). }\end{array}$ & & & & & \\
\hline $\begin{array}{l}\text { 3. The school administration works in close cooperation with health } \\
\text { institutions against the deadly epidemics (avian influenza, Chinese flu, } \\
\text { Crimean Congo, etc.) announced in the media. }\end{array}$ & & & & & \\
\hline $\begin{array}{l}\text { 4. Regular checks are performed by taking necessary precautions against } \\
\text { the parasitic diseases that may be encountered in our school (bits, fleas, } \\
\text { tapeworms, fungae, etc.). }\end{array}$ & & & & & \\
\hline
\end{tabular}

Teacher Perceptions of School Safety in terms of Legislations and Rules

1. I think that discipline committees and regulations against discipline are sufficient.

2. School - family association regulations are sufficient for school safety issues.

3. In our school, the necessary complaints about the problems related to the security applications or the regulations related to the notifications made to the call centers answer the need.

4. I think that the directive on teachers on duty by the Ministry of National Education has fully defined the responsibilities of teachers about school security issues.

\begin{tabular}{|c|c|c|c|c|}
\hline 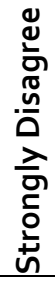 & 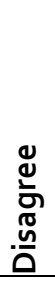 & 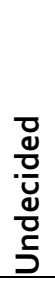 & 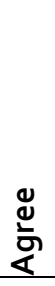 & 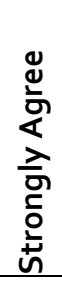 \\
\hline & & & & \\
\hline & & & & \\
\hline & & & & \\
\hline & & & & \\
\hline & & & & \\
\hline
\end{tabular}

\begin{tabular}{|c|c|c|c|c|c|}
\hline Teacher Perceptions of School Safety in terms of Environment & 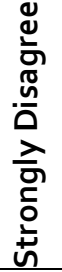 & 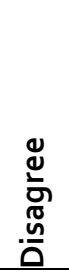 & 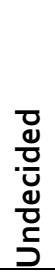 & 巡 & 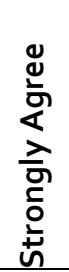 \\
\hline 1. There are terrorist incidents in our school. & & & & & \\
\hline 2. There are drug users and dealers around our school. & & & & & \\
\hline
\end{tabular}


3. The fact that our school students are able to easily provide the publication (pornographic publications and visuals) poses a threat to school security.

4. There are security risks in the vicinity of the school, such as transformers, fuel stations, base stations or airports.

\begin{tabular}{|c|c|c|c|c|c|}
\hline $\begin{array}{l}\text { Teacher Perceptions of School Safety in terms of Violence (Physical, } \\
\text { Sexual, Psychological etc.) }\end{array}$ & 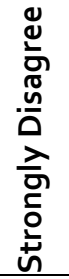 & 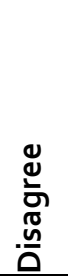 & 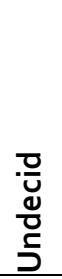 & 产 & 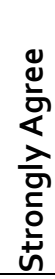 \\
\hline \multicolumn{6}{|l|}{$\begin{array}{l}\text { 1. I have witnessed the introduction of firearms or cutting tools to the } \\
\text { school by students/teachers/administrators/other personnel. }\end{array}$} \\
\hline \multicolumn{6}{|l|}{ 2. I witnessed parents' physical violence against teachers. } \\
\hline \multicolumn{6}{|l|}{$\begin{array}{l}\text { 3. Mobbing (psychological pressure, mobbing, intimidation, } \\
\text { intimidation, harassment) events are experienced in our school. }\end{array}$} \\
\hline \multicolumn{6}{|l|}{ 4. At school, students use physical violence against teachers. } \\
\hline \multicolumn{6}{|l|}{ 5. In our school, there are often threats and blasphemy incidents. } \\
\hline \multicolumn{6}{|l|}{$\begin{array}{l}\text { 6. Mobbing (psychological pressure, mobbing, intimidation, } \\
\text { intimidation, harassment) events are experienced in our school. }\end{array}$} \\
\hline $\begin{array}{l}\text { 7. There have been students/teachers/administrators/parents who have } \\
\text { suffered or died in violence incidents in our school. }\end{array}$ & & & & & \\
\hline
\end{tabular}

